\title{
UN and the Protection of Environment: the Past, the Present and the Future
}

\author{
Alexandr Solntsev \\ Department of International Law \\ RUDN University \\ Moscow, Russia \\ solntsev_am@rudn.university
}

\begin{abstract}
In order to consistently implement the global environmental agenda and to serve as an authoritative advocate for the global environment, it is necessary to continue to implement the United Nations system-wide environmental strategy and work on reform. It should be noted that any measures aimed at ensuring better coordination between the environmental programs of the UN system should benefit the UN Member States, specialized agencies and other relevant organizations that are making their own efforts to ensure environmental sustainability. This, in turn, will require their active participation in ensuring that the policies of all these organizations are harmonized through coordinated decisions by the relevant intergovernmental parliamentary and governing bodies. The United Nations system-wide strategy on the environment will be effective only if it is supported by the decisions of these intergovernmental bodies and institutions. Despite significant progress, further efforts are needed to ensure better coordination in addressing environmental and related to environment issues, including through the establishment of the United Nations Environment Organization in the form of the specialized agency of the United Nations.
\end{abstract}

Keywords-International environmental law; UNEP; Environmental policy

\section{INTRODUCTION}

Being an integral part of sustainable development, the environment is inseparable from economic and social development. Environmental sustainability is closely linked with economic and social development, being the foundation underlying these processes. Furthermore, the environmental issues, in particular those that are of global importance to the international community have multidimensional nature and various subgroups of environmental, economic and social issues and interests are interrelated.

In 2015, the deadline for the achievement of the Millennium Development Goals (MDGs) formulated by the international community in the 2000 United Nations Millennium Declaration, terminated. For a number of indicators, some objectives had been achieved. In September 2015, the international community adopted a new agenda for the sustainable development for the period 2016-2030. "Transforming our world: the 2030 Agenda for Sustainable Development", which identified 17 Sustainable Development Goals (SDGs), followed by 169 objectives, reaffirmed commitments for the global partnership for development and defined the basic principles of accountability for the implementation of these goals.

The goals and objectives are extremely important, but which of the UN departments, sectors or funds will monitor the implementation of the SDGs? - Indeed, each of the institutions, including most of the bodies, funds, programs and specialized agencies of the UN system, has its own specific mandate and limited jurisdiction. In view of the autonomy enjoyed by their governing structures in the decision-making process, policies and actions in regard to the environment and relevant issues related to their respective mandates are often determined regardless of the decision-making processes and activities of other organizations dealing with the same or similar problems.

Against this background, organizations were repeatedly called upon to strengthen coordination of their environmental policy and activities and related issues [Sokolova, 2008, p. 98106]. Although significant progress has already been made in this endeavor, further efforts are needed to ensure better coordination to solve environmental issues and related to environment concerns, including in the context of the environmental programs of the UN bodies, funds, programs and specialized agencies.

\section{THEORETICAL GROUNDS FOR THE RESEARCH}

The 1945 UN Charter does not directly establish the competence to protect the environment. Indeed, the environmental imperative in the international arena was raised at the turn of the $60 \mathrm{~s}-70 \mathrm{~s}$ of the XXth century, which led in 1972 to the holding of the United Nations Conference on the Human Environment and the establishment of the special body under the UN General Assembly - the United Nations Environment Programme (UNEP). Another significant milestone in strengthening the UN's environmental competence was the creation after the 1992 United Nations Conference on Environment and Development (Rio de Janeiro) of the special body under ECOSOC, the Commission on Sustainable Development (CSD).

Specially created UNEP under the UN General Assembly and the CSD under ECOSOC, as well as strengthening the environmental competency of a number of the UN bodies (the International Law Commission, the Space Committee, etc.) and the specialized agencies of the United Nations (FAO, UNESCO, WHO, etc.) solved undoubtedly a lot of environmental problems, but not all of them. The United 
Nations has repeatedly been called for increased coordination of the environmental policy and appropriate activities. Although significant progress has been made in this endeavor, but further efforts are needed to ensure better coordination in addressing environmental issues and problems related to the environment. The crucial decision could be the creation of the United Nations Environmental Organization (UNEO) or the United Nations Environment Protection Organization (UNEPO)) [Bharat, 2014] as the specialized UN agency. However, the international community chose another way: strengthening the activities and increasing the effectiveness of the existing bodies.

\section{RESEARCH: THE MAIN PART}

The Rio +20 summit in 2012 has been followed by significant changes in the institutional framework for the UN's environmental activities:

1. The transformation of the CSD into the Intergovernmental High-Level Political Forum which later adopted the Sustainable Development Goals for 2016-2030;

2. The transformation of the UNEP Governing Council (58 members) into the United Nations Environment Assembly of the UNEP (193 members).

Let's consider these innovations consistently.

Transformation of the United Nations Commission on Sustainable Development into the United Nations Intergovernmental High-Level Political Forum. The United Nations Commission on Sustainable Development was established in December 1992 by the UN General Assembly Resolution 47/191 as the functional Commission of the United Nations ECOSOC in order to implement the global agreement reached in June 1992 at the Rio Summit on Environmental Protection. The CSD held twenty sessions. The last session took place on September 20, 2013. The Commission undoubtedly will go down in history as the authority that has achieved the strengthening of "relations between people and the planet". However, in the report on the conclusions related to the activities of the Commission the former UN SecretaryGeneral Ban Ki-moon has also pointed out some shortcomings in the Commission's work. The former head of the UN considered the inability of the Commission to integrate the economic, social and environmental aspects of sustainable development into a single formula as the main weakness of its activities ${ }^{1}$.

It should be noted that the Commission was the first UN body to deal with sustainable development and the "green" economy. It became the launching pad for a number of initiatives, agreements and organizations, but over time, its participants found that the progress on the sustainable development was too slow, and that the activities at the higher level were needed. At the Rio +20 summit, which was held in the same place in 2012, its participants decided to create the "Intergovernmental High-Level Political Forum" to discuss issues of the sustainable development. On July 10, 2013, the

1 UN Doc. A/ 67/757 dated 26.02.2013 "Lessons learned from the Commission on Sustainable Development".
UN General Assembly adopted Resolution 67/290 on the establishment of the Intergovernmental High-Level Political Forum on Sustainable Development. The forum is the universal body, in contrast to its predecessor, the Commission, which included 53 Member States and was the subsidiary body of the United Nations Economic and Social Council. The sessions of the new Intergovernmental High-Level Political Forum are convened under the auspices of the UN General Assembly and the Economic and Social Council. Representatives of all Member States of the UN and Member States of the specialized UN agencies take part in these sessions. The Forum's sessions will be held under the auspices of the UN General Assembly at the level of Heads of States and governments every four years, and under the auspices of the United Nations Economic and Social Council - annually for eight days, including a three-day ministerial meeting. The first meeting was held on September 24, 2013, and it was this Forum that developed the Sustainable Development Goals (SDGs) until 2030, of which we spoke above, and will continue to participate in their achievement.

Transformation of the UNEP Governing Council into the United Nations Environment Assembly UNEP. In December 2012, following the outcome of the Rio + 20 summit, the UN General Assembly decided to "strengthen and enhance the status" of the United Nations Environment Programme (UNEP) and the establishment of the universal membership in its governing body. Prior to the adoption of this resolution, the UNEP Governing Council was composed of only 58 members. In March 2013, the UN General Assembly approved by the Resolution 67/251 the establishment of the United Nations Environment Programme (the United Nations Environment Assembly UNEP), which includes representatives of all 193 UN Member States, instead of the UNEP Governing Council of the United Nations Environment Assembly ${ }^{2}$.

In its Resolution, the UN General Assembly stated that the new definition does not change "the present mandate, aims and purposes of the United Nations Environment Programme or the role and functions of its governing body". The main tasks of the UNEP include the following: to analyze and to assess of the global environment, to prevent environmental threats, to develop international environmental law for the sustainable development, to promote public awareness of the international environmental policies and activities, to provide assistance in the policy development and the provision of the advisory services by the governmental and non-governmental organizations.

The first session of the Assembly was held in Nairobi from 23 to 27 June 2014 on "A Decent Life for All". The meeting participants discussed a wide range of issues, including illegal trade of the wild species of animals and plants, air and marine pollution, certain aspects of environmental law and financing projects for the development of the "green economy".

The Executive Director of the UNEP said that the convening of the UN Assembly on the Environment means

${ }^{2}$ Resolution of the UN General Assembly 67/251 of March 13, 2013 "Change of the designation of the Governing Council of the United Nations Environment Programme". 
that today environmental issues are given the same attention as problems of peace, security, finance, health and trade. He emphasized that participation in the Assembly of all the UN Member States testifies its indisputable legitimacy. "We must seize this historic opportunity here in Nairobi - so close to the Rift Valley, the cradle of mankind - to unite the world in its effort to achieve a course correction and shape a new, more sustainable future for humanity, one in which we live in harmony with the natural world and create a life of dignity for all", added the head of the UNEP ${ }^{3}$.

The coordinating role in the field of the environment, which the UNEP plays in the UN system, must be strengthened. To ensure effective coordination in order to improve policy coherence, as well as planning and implementation of environmental and related activities throughout the UN system, the Executive Director should initiate, in cooperation with all appropriate UN bodies, funds, programs and specialized agencies the process of preparing the proposal for the United Nations system-wide strategy on the environment, which could be guided in the medium-term and long-term planning of environmental programs within the UN system.

Among other measures to strengthen the UNEP the following should be noted: encouraging active cooperation between scientists and policy-makers on the basis of existing international agreements, evaluation activities, discussion groups and information networks; distribution of scientifically valid environmental information, exchange of such information and raising public awareness of vital and emerging environmental problems; and to ensure the national capacity development as well as to support the States in their access to technology, implementation, and the special attention within this kind of strategy should probably be given to assisting the UN Member States, specialized agencies and other relevant organizations in achieving internationally agreed environmental goals and objectives. The following thematic clusters of existing internationally agreed environmental goals and objectives give an idea of the possible thematic areas that could be collectively or independently reviewed by the United Nations bodies, funds, programs and specialized agencies: a) air pollution and air quality;

b) biodiversity; c) chemicals and wastes; d) climate change; e) power engineering; f) forests;

fresh water; h) oceans and seas; i) soils, land use, soil degradation and desertification; management.

j) environmental

It can be noted that a number of bodies, funds, programs and specialized agencies of the UN system are actively working in each of the above mentioned thematic area groups, which perform certain functions in accordance with their respective mandates. In addition, under each of these functions, several stakeholders can conduct actions related to a lot of thematic areas. For example, such cross-sectoral functions could include the collection of data and information on the environmental issues, evaluation, the development of norms, standards, procedures and international legal instruments and support for their application, as well as the capacity-building.

Accordingly, ways and measures to ensure the coherence of the policies of the various bodies, funds, programs and specialized agencies of the United Nations system in the environmental field can be assessed in the context of the above mentioned thematic areas and cross-sectoral functions, on the basis of which the contents of the possible United Nations system-wide strategy on the environment could be considered.

It should be noted that any measures aimed at ensuring better coordination between the environmental programs of the UN system should be beneficial to the UN Member States, specialized agencies and other relevant organizations making their own efforts to ensure the environmental sustainability. This, in turn, will require their active participation in ensuring that the policies of all these organizations are harmonized through coordinated decisions by the relevant intergovernmental parliamentary and governing bodies. The United Nations system-wide strategy on the environment will be effective only if it is supported by the decisions of these intergovernmental bodies and institutions.

At the inter-agency level, the contribution to the proposed process can be facilitated through the relevant inter-agency coordination mechanisms of the UN system. The Environmental Management Group, which functions as the voluntary inter-agency coordination mechanism throughout the United Nations system, and which is organizationally separated from the UNEP, can facilitate the dialogue process between the secretariats of the relevant United Nations bodies, funds, programs and specialized agencies, based on the work undertaken by the Executive Director. In addition, the Secretary-General may be invited to assist efforts to ensure that the executive heads of the United Nations bodies, funds, programs and specialized agencies contribute to this process, particularly in the context of the UN System Chief Executives Board for Coordination.

However, it should be also noted that since the secretariats of each of these bodies, funds, programs and specialized agencies are guided by the mandates and the program framework established by the Member States and the governing bodies of the appropriate organizations, with respect to their activities to ensure coherence in the environmental policy, eventually, the decision of these governing bodies should be adopted or approved. Such institutional support provided by the coordinated intergovernmental decisions shall be a key factor in achieving the effectiveness and viability of any United Nations systemwide strategy on the environment.

\footnotetext{
${ }^{3}$ The first UN Assembly on the Environment was held in Nairobi. URL: http://www.un.org/russian/news/ story.asp?newsID=21843\#.U6kMx_1_tl0.
} 


\section{CONCLUSION}

In order to consistently implement the global environmental agenda and to serve as an authoritative advocate for the global environment, it is necessary to continue to implement the United Nations system-wide environmental strategy and work on reform. It should be noted that any measures aimed at ensuring better coordination between the environmental programs of the UN system should benefit the Member States, specialized agencies and other relevant organizations that are making their own efforts to ensure environmental sustainability. This, in turn, will require their active participation in ensuring that the policies of all these organizations are harmonized through coordinated decisions by the relevant intergovernmental parliamentary and governing bodies. The United Nations system-wide strategy on the environment will be effective only if it is supported by the decisions of these intergovernmental bodies and institutions. Despite significant progress, further efforts are needed to ensure better coordination in addressing environmental and related to environment issues, including through the establishment of the United Nations Environment Organization in the form of the specialized agency of the United Nations.

\section{ACKNOWLEDGMENT}

The paper is prepared under the project N 16-18-10315 funded by Russian Science Foundation at Saint Petersburg State University.

\section{REFERENCES}

[1] Sokolova N.A. The mechanism of international management of the UN system in the field of environmental protection // Journal of Russian Law. - Moscow: Norma, 2008, № 8. - P. 98-106.

[2] Desai Bharat. International environmental governance: towards UNEPO. Leiden, 2014. 